\title{
Dok. 2. \\ Posiedzenie Rady Europejskiej w Brukseli 15 i 16 października 2008 r. Konkluzje prezydencji
}

Rada Europejska zebrała się w dniach 15 i 16 października 2008 r. w sytuacji naznaczonej międzynarodowym kryzysem gospodarczym i finansowym. Rada Europejska wyraziła zamiar podjęcia skoordynowanych i globalnych działań mających na celu ochronę europejskiego systemu finansowego, a także deponentów. Rada Europejska potwierdziła cel, jakim jest osiągnięcie przed końcem roku całościowego porozumienia w sprawie pakietu dotyczącego energii/klimatu. Uzgodniła, że należy przyspieszyć prace nad bezpieczeństwem energetycznym. Przyjęła Europejski pakt o imigracji i azylu. Jeśli chodzi o stosunki zewnętrzne, Rada Europejska dokonała podsumowania realizacji przez Rosję porozumienia z 8 września, sytuacji w Gruzji oraz stosunków UE ze wschodnimi sąsiadami. Rada Europejska wysłuchała analizy na temat irlandzkiego referendum w sprawie traktatu z Lizbony, którą przedstawił premier Irlandii; Rada powróci do tej kwestii w grudniu. Rada Europejska zatwierdziła skład grupy refleksji nad przyszłością Unii.

Posiedzenie Rady Europejskiej zostało poprzedzone wystapieniem Hansa-Gerta Pötteringa, przewodniczącego Parlamentu Europejskiego, po czym nastąpiła wymiana poglądów.

\section{SYTUACJA GOSPODARCZA I FINANSOWA}

1. W sytuacji kryzysu finansowego Rada Europejska potwierdza, że jest zdecydowana działać w sposób skoordynowany i całościowy, by przywrócić właściwe funkcjonowanie systemu finansowego, a tym samym zapewnić normalne i efektywne finansowanie gospodarki powrócić na drogę wzrostu i zatrudnienia.

2. Rada Europejska z zadowoleniem przyjmuje środki podejmowane od początku kryzysu finansowego przez Europejski Bank Centralny i krajowe banki centralne, jak również dobrą koordynację ich działań z bankami centralnymi krajów partnerskich. Wszystkie organy zapewnią płynność systemu finansowego w celu ochrony zaufania i stabilności.

3. Rada Europejska przychylnie odnosi się do wspólnego planu działania państw strefy euro $\mathrm{z} 12$ października i przyjmuje jego zasady. Z zadowoleniem przyjmuje równieź środki zastosowane przez państwa członkowskie, zarówno należące, jak i nienależące do strefy euro, zgodnie $\mathrm{z}$ zasadami tego planu i z poszanowaniem Traktatu. Nadal obowiązują środki krajowe już zatwierdzone przez Komisję. Rada Europejska apeluje do państw członkowskich o dopilnowanie, by środki krajowe zastosowane przez nie w przyszłości również były zgodne z tymi zasadami, i o uwzględnienie ewentualnych skutków podjętych przez nie decyzji dla pozostałych państw członkowskich. 
4. Rada Europejska potwierdza swoje zobowiązanie do tego, że we wszystkich okolicznościach zastosowane zostaną środki niezbędne do zachowania stabilności systemu finansowego, wsparcia ważnych instytucji finansowych, zapobieżenia bankructwom i zapewnienia ochrony depozytów osób oszczędzających. Środki te mają przede wszystkim - w porozumieniu $\mathrm{z}$ bankami centralnymi oraz organami nadzoru - zapewnić dostateczną płynność instytucjom finansowym, ułatwić ich finansowanie oraz dostarczyć im zasobów kapitałowych, by mogły nadal w normalny sposób finansować gospodarkę.

5. Rada Europejska uważa, że środkom wsparcia na rzecz instytucji finansowych borykających się z trudnościami powinny towarzyszyć środki umożliwiające zapewnienie ochrony podatników, przyjęcia odpowiedzialności przez kierownictwo i akcjonariuszy oraz ochrony uzasadnionych interesów innych podmiotów na rynku. W obecnych wyjątkowych okolicznościach stosowanie europejskich zasad należy nadal podporządkowywać wymogom szybkiego i elastycznego działania. Rada Europejska wspiera Komisję w stosowaniu w tym duchu zasad dotyczących polityki konkurencji, zwłaszcza w odniesieniu do pomocy państwa, przy dalszym przestrzeganiu zasad jednolitego rynku i zasad pomocy państwa.

6. Aby umożliwić szybką i skuteczną reakcję w sytuacji kryzysowej, wprowadzony zostanie nieformalny mechanizm ostrzegania, wymiany informacji i oceny (komórka ds. kryzysu finansowego). W mechanizm ten zaangażowani będą przedstawiciele państwa sprawującego przewodnictwo w Radzie, przewodniczącego Komisji, prezesa EBC (w porozumieniu z pozostałymi europejskimi bankami centralnymi), przewodniczącego Eurogrupy, a także rządów państw członkowskich. Opierać się on będzie na istniejących strukturach administracyjnych; każde państwo członkowskie dotknięte kryzysem będzie mogło w każdej chwili z niego skorzystać; mechanizm ten będzie służył niezwłocznemu przekazywaniu poufnych informacji instytucjom i wszystkim państwom członkowskim. Pozwoli on na prawidłową koordynację już podjętych i planowanych działań. Rada Europejska zwraca się do Rady, aby jak najszybciej zakończyła opracowywanie warunków utworzenia i funkcjonowania komórki ds. kryzysu finansowego.

7. Zagwarantowanie zaufania do systemu finansowego i bankowego oraz ochrony interesów deponentów i inwestorów wymaga również od instytucji finansowych, aby ściśle realizowały zalecenia w zakresie przejrzystości ich zobowiązań i ryzyka.

8. Rada Europejska podkreśla potrzebę wzmocnienia nadzoru nad europejskim sektorem finansowym, zwłaszcza nad grupami międzynarodowymi, oraz pilnego wdrożenia harmonogramu Rady ECOFIN z myślą o poprawie koordynacji nadzoru na szczeblu europejskim. W tym kontekście Rada Europejska z zadowoleniem przyjmuje utworzenie przez Komisję grupy wysokiego szczebla. Przede wszystkim Rada Europejska apeluje do krajowych organów nadzoru, aby co najmniej raz w miesiącu zbierały się w celu wymiany informacji. Rada Europejska popiera przyspieszenie prac toczących się nad wzmocnieniem zasad dotyczących stabilności, w tym nad dyrektywami w sprawie wymogów kapitałowych. Rada Europejska apeluje również o szybkie przeanalizowanie wniosku prawodawczego Komisji służącego wzmocnieniu ram prawnych dotyczących agencji ratingowych $i$ ich nadzoru na szczeblu europejskim. Wzywa do podjęcia szybkich decyzji dotyczących rozwoju europejskich zasad bezpieczeństwa depozytów, tak aby zapewnić ochronę osób oszczędzających. Rada Europejska z zadowoleniem przyj- 
muje decyzję dotyczącą standardów rachunkowości i ich interpretacji mających zastosowanie do instytucji finansowych. Ponadto Rada Europejska apeluje o przeprowadzenie - w porozumieniu z partnerami międzynarodowymi - ogólniejszej refleksji na temat skutków stosowania standardów rachunkowości na podstawie wartości teoretycznej i na podstawie wyceny rynkowej dla instytucji finansowych i dla rynku, w tym na temat ich skutków procyklicznych.

9. Aby skorzystać z doświadczeń zebranych podczas obecnego kryzysu i odbudować zaufanie społeczeństwa, Rada Europejska stanowczo apeluje do przyjęcia odpowiedzialności przez wszystkie podmioty systemu finansowego, zwłaszcza sektora bankowego. Podkreśla, że rzeczywiste wyniki kierowniczych kadr przedsiębiorstw powinny znaleźć odbicie w ich wynagrodzeniu, w tym odprawach (,złoty spadochron”), które powinny zależeć od z rzeczywistego wkładu osoby na stanowisku kierowniczym w osiągnięcie przez spółkę dobrych wyników. W ten sam sposób należy zadbać o to, by zyski z opcji na akcje lub system wynagrodzeń, zwłaszcza w sektorze finansowym, nie pociągały za sobą nadmiernego ryzyka ni nadmiernej koncentracji na celach krótkoterminowych. Rada Europejska wzywa państwa członkowskie do działań na rzecz zastosowania tych zasad i zwraca się do Rady o porządzenie do końca roku sprawozdania z podjętych decyzji.

10. Poza kwestią sektora finansowego Rada Europejska podkreśla, że jest zdecydowana przedsięwziąć środki niezbędne do tego, by wspierać wzrost gospodarczy i zatrudnienie. Zwraca się do Komisji o sformułowanie do końca roku odpowiednich propozycji służących w szczególności utrzymaniu międzynarodowej konkurencyjności przemysłu europejskiego. Rada Europejska podkreśla, że kontynuowanie reform strukturalnych jest ważniejsze niż kiedykolwiek, aby przyczynić się do przywrócenia wzrostu i poprawy zatrudnienia w Europie. Wsparcie działalności gospodarczej następuje dzięki odpowiedniemu poziomowi finansowania. Rada Europejska z zadowoleniem przyjmuje decyzję Europejskiego Banku Inwestycyjnego o uruchomieniu kwoty 30 miliardów EUR przeznaczonej na wsparcie europejskich MŚP, a także zobowiązanie tej instytucji do zwiększenia możliwości jej udziału $\mathrm{w}$ projektach infrastrukturalnych. Wzywa EBI do podejmowania w większym zakresie ryzyka związanego $\mathrm{z}$ finansowaniem MŚP.

11. Polityki budżetowe powinny nadal wpisywać się $w$ ramy zmienionego paktu stabilności i wzrostu, którego realizacja powinna także odzwierciedlać - zgodnie z jego zasadami - wyjątkowe okoliczności, w jakich się znajdujemy.

12. Unia Europejska powinna działać ze swoimi partnerami międzynarodowymi na rzecz rzeczywistej i kompletnej reformy międzynarodowego sektora finansowego opartej na zasadach przejrzystości, solidności bankowej, odpowiedzialności, integralności i globalnego zarządzania. Celem tych działań jest szybkie podjęcie decyzji dotyczących przejrzystości, ogólnoświatowych standardów regulacji, transgranicznego nadzoru i zarządzania kryzysowego, unikania konfliktu interesów i stworzenia systemu wczesnego ostrzegania, tak by wzbudzić pewność i zaufanie osób oszczędzających i inwestorów w każdym kraju. Unia w szybkim tempie podejmie stosowne inicjatywy w porozumieniu ze swoimi głównymi partnerami i zainteresowanymi międzynarodowymi instytucjami finansowymi. Inicjatywy te zostaną starannie przygotowane w ramach UE.

13. Rada Europejska wyraża solidarność z działaniami podejmowanymi przez Islandię, która jest krajem ściśle zintegrowanym z jednolitym rynkiem UE na mocy poro- 
zumienia EOG i potrzebuje wsparcia ze strony społeczności międzynarodowej; oczekuje, że kraj ten dotrzyma swoich zobowiązań międzynarodowych.

14. Rada Europejska przyjęła do wiadomości sprawozdanie przygotowane przez prezydencję we współpracy z Komisją dotyczące niestabilności cen ropy. Wzywa Radę do szybkiego podjęcia dalszych prac w tej kwestii i zwraca się do Komisji, aby - w porozumieniu zwłaszcza z Europejskim Bankiem Inwestycyjnym - niezwłocznie podjęła działania niezbędne do propagowania przejrzystości w sprawie komercyjnych zapasów ropy, a także efektywności energetycznej.

\section{TRAKTAT Z LIZBONY}

15. Przypominając swoje konkluzje z czerwca 2008 roku, Rada Europejska przyjęła do wiadomości analizę wyników referendum w sprawie traktatu z Lizbony przedstawioną przez premiera Irlandii, Briana Cowena. Rząd Irlandii będzie kontynuował konsultacje, które mają pomóc w opracowaniu ewentualnego rozwiązania tej sytuacji. W tym kontekście Rada Europejska postanowiła powrócić do tej kwestii na posiedzeniu w grudniu 2008 roku, tak by określić szczegóły rozwiązania i kierunki dalszego postępowania.

\section{ENERGIA I ZMIANY KLIMATU}

16. Rada Europejska potwierdza, że jest zdecydowana dotrzymać ambitnych zobowiązań w dziedzinie polityki w zakresie klimatu i polityki energetycznej, które zatwierdziła w marcu 2007 i w marcu 2008 roku. W tym kontekście zwraca się do prezydencji i Komisji o to, by w najbliższych tygodniach przeprowadziły wzmożone prace, które umożliwią Radzie Europejskiej podjęcie w grudniu 2008 roku decyzji o rozwiązaniach trudności wynikających z wdrażania; rozwiązania powinny być odpowiednie dla wszystkich sektorów gospodarki europejskiej i wszystkich państw członkowskich - z uwzględnieniem sytuacji każdego z nich - i zapewniać przy tym zadowalający i ściśle określony poziom opłacalności.

\section{BEZPIECZEŃSTWO ENERGETYCZNE}

17. Bezpieczeństwo dostaw energii ma dla Unii Europejskiej priorytetowe znaczenie. Aby je zapewnić, potrzebna jest odpowiedzialność i solidarność wszystkich państw członkowskich. W tym kontekście i uwzględniając sprawozdanie przedłożone przez prezydencję, Rada Europejska postanawia zintensyfikować trwające prace, przyjmując następujące wytyczne i zachęcając Komisję, by w razie potrzeby przedstawiła odpowiednie wnioski lub inicjatywy, aby: a) zakończyć prace nad pakietem prawodawczym dotyczącym rynku wewnętrznego energii elektrycznej i gazu ziemnego przed końcem kadencji PE; b) przyspieszyć realizację europejskiego planu działania na rzecz racjonalizacji zużycia energii oraz strategicznego planu w dziedzinie technologii energetycznych; c) zdecydowanie kontynuować działania nad dywersyfikacją źródeł energii, do czego bezpośrednio przyczyniają się środki zaproponowane w pakiecie dotyczącym energii/klimatu; d) wspierać lepsze funkcjonowanie rynku, zwłaszcza dzięki większej przejrzystości w kwestii przepływu i poziomu zapasów oraz wymianie informacji na 
temat dhugoterminowych potrzeb i zasobów; e) rozwinąć mechanizmy kryzysowe, które pozwolą stawić czoła czasowym przerwom w dostawach; f) wzmocnić infrastruktury krytyczne, zwłaszcza transeuropejskie sieci energetyczne i terminale skroplonego gazu ziemnego oraz zakończyć ich tworzenie. Szczególna uwaga zostanie jednocześnie zwrócona na wzajemne połączenia i na przyłączenie najbardziej oddalonych krajów europejskich, połączenia sieci europejskich z infrastrukturą dostawczą i na konieczność dywersyfikacji zarówno źródeł, jak i szlaków zaopatrzeniowych. Rada Europejska popiera inicjatywę Komisji polegającą na opracowaniu planu działania służącego przyspieszeniu wzajemnych połączeń w regionie Morza Bałtyckiego. W tym celu przed końcem roku sporządzony zostanie harmonogram pracy; g) rozwijać stosunki Unii w dziedzinie energii z państwami produkującymi energię i państwami tranzytowymi, mając na uwadze stabilność dostaw, a także dywersyfikację źródeł energii i szlaków zaopatrzeniowych. W tym kontekście Rada Europejska z zadowoleniem przyjmuje inicjatywy podjęte przez niektóre państwa członkowskie w dziedzinie bezpieczeństwa energetycznego, w szczególności spotkanie z państwami regionu Morza Kaspijskiego oraz z państwami tranzytowymi, które zostanie zorganizowane przez prezydencje czeską na wiosnę 2009 roku.

18. Rada Europejska ponownie zajmie się tym zagadnieniem na posiedzeniu w marcu 2009 roku, aby dokonać podsumowania prac i przyjąć odpowiednie decyzje, również w świetle kolejnego strategicznego przeglądu dotyczącego energii, który przedstawi Komisja.

\section{EUROPEJSKI PAKT O IMIGRACJI I AZYLU}

19. Rada Europejska przyjęła Europejski pakt o imigracji i azylu, który jest wyrazem zaangażowania Unii Europejskiej i jej państw członkowskich w prowadzenie sprawiedliwej, skutecznej i spójnej polityki wobec wyzwań i możliwości związanych z migracją. Pakt ten będzie odtąd dla Unii i jej państw członkowskich podstawą wspólnej polityki w zakresie imigracji i azylu, realizowanej w duchu solidarności między państwami członkowskimi i we współpracy z państwami trzecimi. Ta wspólna polityka musi się opierać na właściwym zarządzaniu przepływami migracyjnymi - w interesie nie tylko państw przyjmujących, lecz również państw pochodzenia i samych migrantów.

20. Podstawowe zasady określone w pakcie znajdą odbicie w serii działań, które należy bezzwłocznie wdrożyć zarówno na poziomie Unii Europejskiej, jak i na poziomie krajowym. Ponadto zasadami tymi będą się kierować w szczególności twórcy przyszłego programu pracy Unii Europejskiej, który Komisja przedstawi w maju 2009 roku z myślą o jego finalizacji podczas prezydencji szwedzkiej. Realizacja paktu będzie przedmiotem corocznej debaty na forum Rady Europejskiej, począwszy od jej posiedzenia w czerwcu $2010 \mathrm{r}$.

\section{DZIAŁANIA PODEJMOWANE W NASTECPSTWIE POSIEDZENIA RADY EUROPEJSKIEJ W DNIU 1 WRZEŚNIA 2008 R.}

21. Rada Europejska z satysfakcją przyjmuje wycofanie oddziałów rosyjskich ze stref przyległych do Osetii Pohudniowej i Abchazji jako ważny dodatkowy etap realizacji porozumień z dnia 12 sierpnia i 8 września, jak również rozpoczęcie w Genewie 
międzynarodowych rozmów, które zostały przewidziane w tych porozumieniach. Rada Europejska wzywa Komisję i Radę do dalszego prowadzenia pełnej i dogłębnej oceny stosunków między UE a Rosją z myślą o najbliższym szczycie, który ma się odbyć w Nicei w dniu 14 listopada br. Ocena ta zostanie uwzględniona podczas dalszego etapu negocjacji dotyczących nowej umowy o partnerstwie z Rosją.

22. Unia Europejska jest zdecydowana dalej wspierać swoich wschodnich sąsiadów, zwłaszcza w ramach europejskiej polityki sąsiedztwa, w ich działaniach na rzecz modernizacji gospodarczej i demokratyzacji. Rada Europejska podkreśla w tym kontekście, jak ważne są wyniki szczytu UE/Ukraina w Paryżu, i wzywa do zacieśnienia stosunków między Unią a Republiką Mołdowy i Gruzją zgodnie z konkluzjami Rady z dnia 13 października. Zwraca się do Rady o rozpoczęcie pierwszej analizy propozycji dotyczących przyszłego „partnerstwa wschodniego" Unii Europejskiej, które Komisja ma zamiar przedstawić najwcześniej w listopadzie.

\section{GRUPA REFLEKSJI}

23. Rada Europejska zatwierdziła propozycję przewodniczącego i dwóch wiceprzewodniczących grupy refleksji dotyczącą składu grupy, zamieszczoną w załączniku do niniejszych konkluzji. Grupa jak najszybciej rozpocznie prace i przeprowadzi analize sytuacji zgodnie z mandatem przyjętym przez Radę Europejską w grudniu 2007 r. Sekretariat Generalny Rady zapewni grupie wsparcie materialne i logistyczne.

Zalącznik 1

\section{SKLAD GRUPY REFLEKSJ}

Przewodniczący: Felipe González Márquez, wiceprzewodniczący: Vaira ViTe-Freiberga, Jorma Ollila, członkowie: Lykke Friis, Rem Koolhaas, Richard Lambert, Mario Monti, Rainer Münz, Kalypso Nicolaidis, Nicole Notat, Wolfgang Schuster, Lech Wałęsa.

Załącznik 2

\section{WYKAZ DOKUMENTÓW REFERENCYJNYCH PRZEDSTAWIONYCH RADZIE EUROPEJSKIEJ}

- Europejski pakt o imigracji i azylu (dok. 13440/08 zatwierdzony przez Radę ds. WSiSW w dniu 25 września i przyjęty przez Radę Europejska)

- Deklaracja w sprawie wspólnego europejskiego planu działania państw strefy euro (dok. 14239/08)

- Wytyczne prezydencji opracowane z myślą o kontynuacji prac nad pakietem dotyczącym energii/klimatu (dok. 14240/08 + REV 1 (cs) + REV 2 (en, de, da, sv, lt, mt, $\mathrm{pl}, \mathrm{sk}, \mathrm{sl})$

- Sprawozdanie prezydencji na temat bezpieczeństwa energetycznego (dok. 14090/08)

- Sprawozdanie prezydencji na temat niestabilności cen ropy naftowej (dok. 13266/2/08 REV 2) 14368/08 